\title{
Immunological data from cancer patients treated with Ad5/ 3-E2F-A24-GMCSF suggests utility for tumor immunotherapy
}

\author{
Otto Hemminki ${ }^{1}$, Suvi Parviainen ${ }^{1}$, Juuso Juhila ${ }^{1}$, Riku Turkki², Nina Linder ${ }^{2}$, \\ Johan Lundin ${ }^{2,3}$, Matti Kankainen ${ }^{4}$, Ari Ristimäki ${ }^{5}$, Anniina Koski ${ }^{1}$, Ilkka Liikanen ${ }^{1}$, \\ Minna Oksanen ${ }^{1}$, Dirk M. Nettelbeck ${ }^{6}$, Kalevi Kairemo', Kaarina Partanen7, \\ Timo Joensuu7, Anna Kanerva ${ }^{1,8}$, Akseli Hemminki ${ }^{1,7,9}$ \\ ${ }^{1}$ Cancer Gene Therapy Group, Transplantation Laboratory \& Haartman Institute, University of Helsinki, Helsinki, Finland \\ ${ }^{2}$ Institute for Molecular Medicine Finland (FIMM), Helsinki, Finland \\ ${ }^{3}$ Division of Global Health/IHCAR, Karolinska Institutet, Stockholm, Sweden \\ ${ }^{4}$ CSC - IT Center for Science Ltd, Helsinki, Finland \\ ${ }^{5}$ Department of Pathology, HUSLAB and Haartman Institute, Helsinki, University Central Hospital and Genome-Scale Biology, \\ Research Programs Unit, University of Helsinki, Helsinki, Finland \\ ${ }^{6}$ German Cancer Research Center (DKFZ), Heidelberg, Germany \\ ${ }^{7}$ Docrates Cancer Center, Helsinki, Finland \\ ${ }^{8}$ Department of Obstetrics and Gynecology, Helsinki University Central Hospital, Helsinki, Finland \\ ${ }^{9}$ TILT Biotherapeutics Ltd, Helsinki, Finland
}

Correspondence to:

Akseli Hemminki, e-mail: akseli.hemminki@helsinki.fi

Keywords: Oncolytic, immunotherapy, cancer, ATAP

Received:September 17, $2014 \quad$ Accepted: December 14, $2014 \quad$ Published: February 24, 2015

\section{ABSTRACT}

Oncolytic viruses that selectively replicate in tumor cells can be used for treatment of cancer. Accumulating data suggests that virus induced oncolysis can enhance anti-tumor immunity and break immune tolerance. To capitalize on the immunogenic nature of oncolysis, we generated a quadruple modified oncolytic adenovirus expressing granulocyte-macrophage colony-stimulating factor (GMCSF). Ad5/3-E2F-A24-GMCSF (CGTG-602) was engineered to contain a tumor specific E2F1 promoter driving an E1 gene deleted at the retinoblastoma protein binding site (" $\Delta 24$ "). The fiber features a knob from serotype 3 for enhanced gene delivery to tumor cells. The virus was tested preclinically in vitro and in vivo and then 13 patients with solid tumors refractory to standard therapies were treated. Treatments were well tolerated and frequent tumor- and adenovirus-specific $\mathrm{T}$-cell immune responses were seen. Overall, with regard to tumor marker or radiological responses, signs of antitumor efficacy were seen in $9 / 12$ evaluable patients $(75 \%)$. The radiological disease control rate with positron emission tomography was $83 \%$ while the response rate (including minor responses) was $\mathbf{5 0 \%}$. Tumor biopsies indicated accumulation of immunological cells, especially T-cells, to tumors after treatment. RNA expression analyses of tumors indicated immunological activation and metabolic changes secondary to virus replication.

\section{INTRODUCTION}

Despite progress in cancer prevention, early diagnosis and conventional treatment methods, most metastatic solid tumors remain essentially incurable. One experimental treatment option is oncolytic virotherapy which utilizes the potential many viruses have for replication in tumor cells, followed by lysis. Adenoviruses are the most extensively utilized viruses for gene therapy approaches, and with their well demonstrated safety in thousands of patients, and several positive randomized trials [1-4], they remain a solid platform for innovative 
therapy approaches. In the field of oncolytic viruses, two randomized trials have been completed, both with positive results. An oncolytic adenovirus improved the efficacy of chemotherapy for treatment of metastatic head and neck cancer [5] and a GMCSF armed oncolytic herpes viruses was effective in the treatment of metastatic melanoma [6]. However, overall survival results have not yet been positive on a statistically significant level and thus room for improvement remains.

Adenoviruses are immunogenic viruses [7], and since it seems that the immune response is a major determinant of the antitumor effect of oncolytic viruses $[8,9]$, they have a great potential for cancer therapy utilities. Based on the "danger signal" paradigm [10], the presence of oncolytic viruses within a tumor can act as a provocative danger signal for the immune system. Further, tumor associated antigens (TAAs) are released by oncolysis for presentation to the immune system in an environment conducive for immunity [11-13]. Arming adenovirus with immunostimulatory molecules has been utilized as an approach to further augment immune responses against tumor antigens.

The design of the novel oncolytic virus Ad5/3-E2F$\triangle 24-G M C S F$ incorporates three concepts.

I) Serotype 3 knob for enhanced entry into tumor cells. Most clinical trials performed with adenoviruses thus far are based on serotype 5 or the closely related serotype 2 [4]. The primary receptor for these viruses is the coxsackie adenovirus receptor (CAR) [14] which is often down-regulated in aggressive human tumors [15]. Enhanced delivery to and killing of cancer cells, clinical specimens and xenograft tumors in mice is achieved when the native Ad5 fiber knob is replaced by that of serotype 3 virus, without loss of safety in humans [16, 17]. Supporting the safety of Ad3 components, a completely serotype 3 based oncolytic adenoviruses have shown potential in preclinical [18] and clinical settings [19].

II) E2F1 promoter and $\Delta 24$ deletion of viral E1A for efficient and specific replication in tumor cells. Although previous constructs such as CGTG-101 [9], CGTG-102 [16] and CGTG-103 [20], featuring a single "delta-24" mutation for tumor selectivity, have been safe in patients, there may be advantage for multiple levels of control. Tumor selectivity with "delta-24" occurs after E1A expression, and thus E1A is expressed even in normal cells. E1A can cause toxicity and it may contribute to anti-viral immunity, and there may be some "leaky" activation of late viral proteins, again possibly resulting in toxicity or anti-viral immunity. Thus, it would be appealing to control expression of the mutated E1A with a tumor specific promoter [21]. The human E2F1 promoter is active in most tumor cell lines mutated in the $\mathrm{pRb}$ pathway $[22,23]$ thus facilitating the use of the E2F1 promoter in most if not all tumors [24, 25].

III) Granulocyte macrophage colony-stimulating factor (GMCSF) is a widely used immunostimulatory molecule in oncolytic viruses in clinical settings, now also proven effective in a randomized, global phase 3 melanoma trial which met its primary endpoint of durable response rate $[6,26]$. It is a potent inducer of systemic anti-tumor immunity associated with recruitment and maturation of antigen presenting cells (APCs), mainly dendritic cells, as well as recruitment of cells of the innate immunity arm, including natural killer cells and neutrophils. In immunocompetent Syrian hamsters virally produced GMCSF has been able to activate anti-tumor immune responses, enhancing the efficacy of oncolytic adenovirus [9, 27], and human data is compatible with these notion [9, 16, 20, 28]. An advantage of local production of cytokines is that high concentrations can be achieved where useful (at the tumor site) while retaining lower systemic levels, which can cause adverse events or untoward immunological consequences such as recruitment of myeloid derived suppressor cells [16, 29].

\section{RESULTS}

\section{Preclinical experiments}

The E1A region, E3 region and fiber are genetically modified in Ad5/3-E2F- $\triangle 24-G M C S F$ (Figure 1A). Virally produced GMCSF was tested functional by analyzing the growth of GMCSF dependent TF-1 erythroleukemia cells upon addition of filtered supernatant from Ad5/3E2F- $\triangle 24-G M C S F$ infected A549 cells (Figure 1B top).

The selectivity of Ad5/3-E2F- $224-G M C S F$ was studied in primary human hepatocytes. The levels of infective viral particles remained 15 to 11 fold lower than with the parental oncolytic control virus without the E2F1 promoter (replication controlled only by the $24 \mathrm{bp}$ deletion) and 65 to 19 times lower than in wild type Ad5 infected hepatocytes at 48 and 72 hours, respectively (Figure 1B middle).

To study the selectivity of viral replication in Syrian hamsters, a model reported semipermissive for human adenovirus [16], tumors and livers were collected following virus injection and analyzed for virus copy number (Figure 1B bottom). A secondary peak seen in virus copy number in tumors suggests effective virus DNA replication, while particles remained low in the liver at all time points, suggesting lack of replication in normal cells.

The in vitro efficacy of Ad5/3-E2F- $224-G M C S F$ was evaluated on three cancer cell lines representing non-small cell lung, ovarian and prostate cancer (Figure 1C). Ad5/3E2F- $\triangle 24-G M C S F$ achieved cancer cell killing efficacy comparable to the isogenic control without the E2F1 promoter and wild type Ad5, while being superior to the non-replicative Ad5/3luc1 $(P<0.05)$, which implies retained oncolytic potency despite quadruple genetic modification.

In vivo potency and selectivity of $\mathrm{Ad} 5 / 3-\mathrm{E} 2 \mathrm{~F}-\Delta 24-$ GMCSF was characterized in an immunocompetent Syrian hamster model previously reported semi -permissive for adenoviral replication [30, 31]. Subcutaneous hamster pancreatic cancer (HapT1) tumors were treated with 


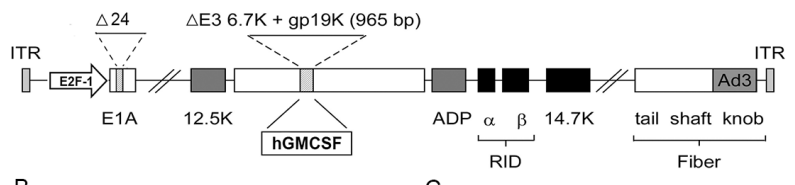

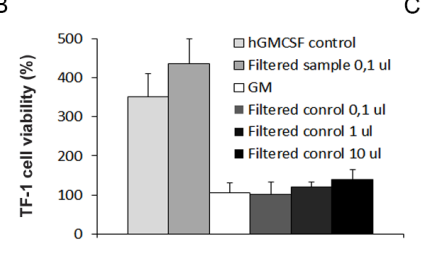
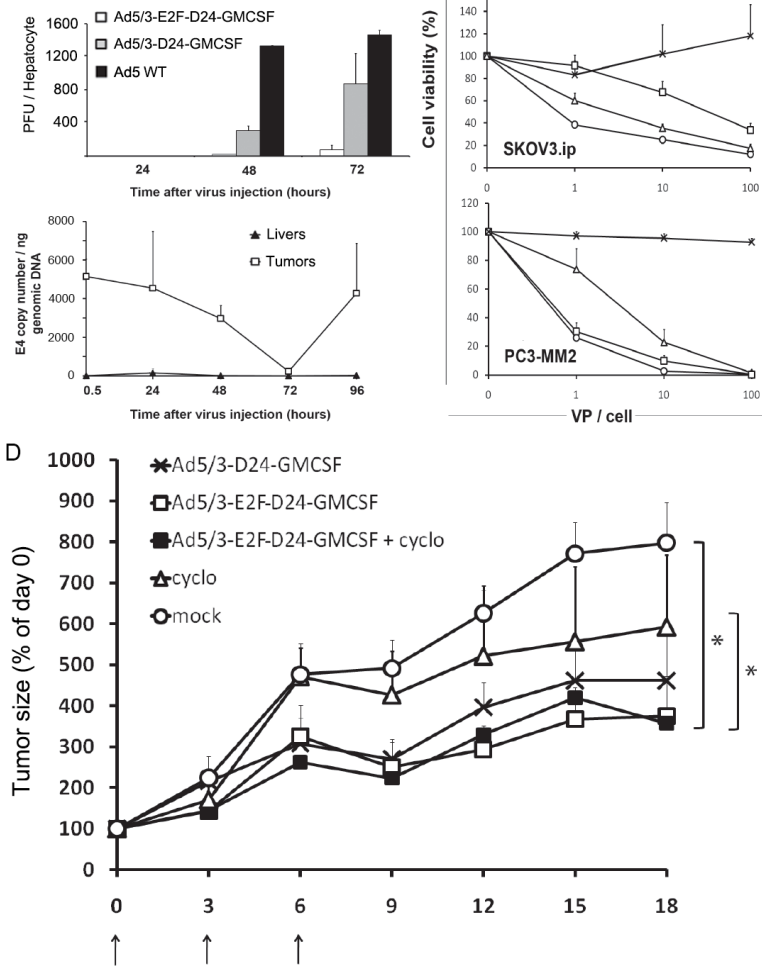

Figure 1: (A) A schematic representation of the Ad5/3-E2F- 2 24-GMCSF virus. The $E 1 A$ promoter is replaced by a human $E 2 F 1$ promoter, which controls the transcription of the $E 1 A$ gene. The $E 1 A$ gene features a 24 base-pair deletion to avoid the self-activation of the promoter by E2F released by E1A-Rb interaction, a critical fault in previous designs with an intact E1 A gene. Gp19k and $6.7 \mathrm{~K}$ in $E 3$ have been replaced with the cDNA of human GM-CSF. The serotype 5 (Ad5) fiber knob has been replaced by the serotype 3 (Ad3) knob. (B) Top panel: Ad5/3-E2F- $\Delta 24-$ GMCSF -expressed GMCSF is functionally active. TF1 cells, which require human GMCSF for viability, were cultured in the presence of human recombinant GMCSF or filtered supernatant from virus infected cells. As a control, supernatant from cells infected with a virus not expressing GM-CSF was used (Ad5/3- $\Delta 24)$. The viability of TF1-cells treated with growth medium (GM) only was set as $100 \%$ hGMCSF control and filtered supernatant showed significantly $(P<0.001)$ higher viability over GM, while no difference was seen between other groups. Middle panel: Less infective virus particles were produced by Ad5/3-E2F- $\triangle 24-\mathrm{GMCSF}$ in human primary hepatocytes at 48 and $72 \mathrm{~h}$ time points compared to the control viruses, indicating low replication in normal human cells. Bottom panel: to evaluate tumor selectivity of the virus, livers of non-tumor-bearing Syrian hamsters were injected and no viral E4 copy number increase was detected with qPCR. In contrast, E4 copy number increased in HapT-1 tumors. Replacing the native E1A promoter with the E2F-1 promoter does not impair virus replication and cell killing effect in vitro (C) or in vivo (D). (C) Results of a cell viability assay shows the cell killing efficiency of Ad5/3-E2F- $224-$ GMCSF compared to Ad5/3- $\triangle 24-$ GMCSF - a control virus bearing the genetically intact E1A promoter - a wild type serotype 5 virus and a non-replicating control virus Ad5/3luc1 in A549 lung cancer cells, SKOV3ip.1 ovarian cancer cells and PC3-MM2 prostate cancer cells. (D) Ad5/3-E2F- $224-$ GMCSF significantly $(P<0.01)$ slowed down tumor progression compared to the mock (growth medium only) animals in Syrian Hamsters bearing pancreatic cancer tumors. $3 \times 10^{8} \mathrm{VP}$ of virus was administered intratumorally on days 0,3 and 6 . Concomitant low dose cyclophosphamide did not significantly improve the anti-tumor effect of Ad5/3-E2F- $\triangle 24-G M C S F$. 
intratumoral injections (Figure 1D) and Ad5/3-E2F- $\Delta 24-$ GMCSF restricted tumor progression significantly when compared to cyclophosphamide only or to mock (growth medium only) treated groups. The recent discovery that not all hamster tumor cell lines are fully permissive to $5 / 3$ chimeric virus - in comparison to human substrates - may have impacted efficacy in this experiment [32]. To evaluate the ability of Ad5/3-E2F- $\Delta 24-$ GMCSF to cause oncolysis of HapT1 cells, a cell killing assay was performed. Interestingly, and in contrast to many other hamster cell lines [28], HapT1 did not allow for productive oncolysis (Figure S1) and therefore the anti-tumor effect was caused by immune response towards tumor cells filled with virus components (virus DNA replicated) and surrounded by GMCSF.

\section{Patients}

Thirteen patients with advanced metastatic tumors refractory to and progressing after standard therapy were treated with 2-4 rounds of Ad5/3-E2F- $224-\mathrm{GMCSF}$ (Table 1). Treatments were performed in a personalized manner and 1-10 tumor sites were injected. Patient C332 received only 1 round of treatment and then underwent pre-planned surgery. Most patients had received multiple lines of chemotherapy before virus treatments and were progressing, thus constituting a highly treatment refractory patient population (Table S1). There was variation between tumors and patients, and thus the patient population well represents "real-life" patients with advanced cancer [33-35].

\section{Safety of the treatments}

Table S2 summarizes the adverse reactions recorded during all 39 treatment rounds. Grade 1-2 flu like symptoms, fever, fatigue and pain were experienced in more than half of the treatments. Most grade 3 events were self-limiting or treatable as outpatient, and no grade 4 or 5 adverse effects were observed.

\section{Virus replication}

All patients evaluated for the presence of Ad5/3E2F- $\triangle 24-G M C S F$ in serum were negative prior to therapy $(N=11$, Table 2$)$. One day after the first treatment $8 / 13$ patients had measurable virus genomes, with the highest titer being $1141 \mathrm{VP} / \mathrm{ml}$. 2/4 patients sampled on days 3-8 were positive, with the highest titer of $11523 \mathrm{VP} / \mathrm{ml}$ serum, and both (O340 and H344) showed an increase in titer after day 1, suggestive of virus replication.

Typically, titers less than $500 \mathrm{VP} / \mathrm{ml}$ were seen 1 day after the second and third treatments while no virus

Table 1: Patients at baseline

\begin{tabular}{|c|c|c|c|c|c|c|}
\hline Patient ID & Age (y) & $\operatorname{Sex}$ & Diagnosis & WHO & Virus Dose** & Treatment rounds \\
\hline $\mathrm{O} 314$ & 62 & $\mathrm{~F}$ & Ovarian cancer & 1 & $1-3 \times 10^{11}$ & 3 \\
\hline $\mathrm{O} 337$ & 69 & $\mathrm{~F}$ & Ovarian cancer & 2 & $5 \times 10^{11}$ & 3 \\
\hline $\mathrm{O} 340$ & 74 & $\mathrm{~F}$ & Ovarian cancer & 0 & $5 \times 10^{11}$ & 3 \\
\hline O351 & 72 & $\mathrm{~F}$ & Ovarian cancer & 2 & $3 \times 10^{11}$ & 3 \\
\hline C312 & 54 & M & Rectum cancer & 1 & $1-3 \times 10^{11}$ & 3 \\
\hline $\mathrm{C} 332 *$ & 49 & $\mathrm{~F}$ & Colon cancer & 0 & $8 \times 10^{11}$ & 1 \\
\hline H192 & 54 & M & $\begin{array}{l}\text { Pancreatic } \\
\text { cancer }\end{array}$ & 1 & $3 \times 10^{11}$ & 2 \\
\hline H344 & 58 & $\mathrm{~F}$ & $\begin{array}{l}\text { Pancreatic } \\
\text { cancer }\end{array}$ & 1 & $8 \times 10^{11}$ & 3 \\
\hline I347 & 51 & M & Melanoma & 2 & $5 \times 10^{11}$ & 3 \\
\hline R319 & 67 & $\mathrm{~F}$ & Breast cancer & 1 & $3-5 \times 10^{11}$ & 3 \\
\hline R342 & 54 & $\mathrm{~F}$ & Breast cancer & 2 & $3 \times 10^{11}$ & 2 \\
\hline R356 & 40 & $\mathrm{~F}$ & Breast cancer & 1 & $1 \times 10^{12}$ & 4 \\
\hline S352 & 59 & $\mathrm{~F}$ & Sarcoma & 1 & $3-10 \times 10^{11}$ & 3 \\
\hline S354 & 50 & $\mathrm{~F}$ & Fibrosarcoma & 2 & $3 \times 10^{11}$ & 4 \\
\hline
\end{tabular}

*Hyperthermic intraperitoneal chemotherapy (HIPEC) surgery 3 weeks later, thus included only for immunohistochemistry analysis.

**First treatment was given at the lower indicated dose. All patients (excluding C332) received low dose cyclophosphamide to reduce T-reg cells, patients H192, H344, I347, S352 and S354 received also low dose pulse temozolomide to enhance autophagy resulting from oncolysis. 
$(N=21)$ was seen on other days after the second and third treatments. These data are compatible with replication of the virus in tumors, especially subsequent to the first injection, with less release of genomes into the circulation occurring after 2 nd and 3rd injection.

\section{Neutralizing antibodies and anti-hexon antibodies}

At baseline, 4 patients had a low titer (1-64) of antiAd5/3 neutralizing antibodies (Table 2). 4 patients had an intermediate titer (256) while 2 patients had a high titer (4096) already at baseline. Thus, at baseline the median titer was 256 and by the time of the second treatment the titer had risen $(P<0.01)$ to a median of 4096 and stayed there until the end of follow-up.

To provide an alternative view on anti-viral antibodies, we also analyzed patient serums for antihexon $\mathrm{IgG}$, hexon being the main capsid protein of the virus. At baseline, all patient serums had low titers (between 30 and 200U/ml) of anti-hexon IgG. Three weeks after the first treatment all patients showed

Table 2: Responses, survival and amounts of virus and neutralizing antibodies

\begin{tabular}{|c|c|c|c|c|c|c|c|c|c|c|c|c|c|c|}
\hline \multirow{4}{*}{$\begin{array}{l}\text { Patient } \\
\text { ID }\end{array}$} & \multicolumn{11}{|c|}{ Virus load in serum (copy number) or Neutralizing Antibody Titer (NAb) } & \multicolumn{3}{|c|}{ Treatment responses } \\
\hline & \multicolumn{11}{|c|}{$\begin{array}{l}\text { Days post } \\
\text { treatment }\end{array}$} & \multirow{3}{*}{$\begin{array}{l}\text { PET } \\
\text { response } \\
(\%)\end{array}$} & \multirow[t]{3}{*}{ Marker } & \multirow[t]{3}{*}{$\begin{array}{l}\text { Survival } \\
\text { (days) }\end{array}$} \\
\hline & & \multicolumn{3}{|c|}{ after $1 \mathrm{st}$} & \multicolumn{3}{|c|}{ after $2 \mathrm{nd}$} & \multicolumn{4}{|c|}{ after 3rd } & & & \\
\hline & & 0 & 1 & $3-8$ & 0 & 1 & $3-8$ & 0 & 1 & $3-10$ & $14-55$ & & & \\
\hline \multirow[t]{2}{*}{$\mathrm{O} 314$} & Virus & 0 & 0 & & 0 & $<500$ & & & 0 & 0 & 0 & & $\mathrm{mPR}$ & 71 \\
\hline & NAb & 1 & & & & & & 1024 & & & & & & \\
\hline $\mathrm{O} 337$ & Virus & 0 & $<500$ & & & 0 & & 0 & $<500$ & & & & $\mathrm{mSD}$ & 276 \\
\hline \multirow[t]{2}{*}{$\mathrm{O} 340$} & Virus & 0 & 1141 & 3608 & 0 & $<500$ & 0 & 0 & $<500$ & 0 & 0 & $\begin{array}{c}\text { MMR } \\
(-10 \%) \\
\end{array}$ & $\mathrm{mCR}$ & 890 \\
\hline & $\mathrm{Nab}$ & 4096 & & & & & 4096 & & & & & & & \\
\hline \multirow[t]{2}{*}{ O351 } & Virus & & 0 & & 0 & $<500$ & 0 & 0 & 0 & 0 & & & $\mathrm{mMR}$ & 87 \\
\hline & $\mathrm{NAb}$ & 256 & & & & & & & 4096 & & & & & \\
\hline \multirow[t]{2}{*}{ C312 } & Virus & 0 & $<500$ & & 0 & $<500$ & & & $<500$ & & & $\begin{array}{c}\text { SMD } \\
(+23 \%)\end{array}$ & $\mathrm{mPD}$ & 397 \\
\hline & $\mathrm{Nab}$ & 4096 & & & & & & 4096 & & & & & & \\
\hline \multirow[t]{2}{*}{ H192 } & Virus & 0 & 0 & & 0 & $<500$ & & & & & & & $\mathrm{mPD}$ & 80 \\
\hline & $\mathrm{Nab}$ & 256 & & & & 4096 & & & & & & & & \\
\hline \multirow[t]{2}{*}{$\mathrm{H} 344$} & Virus & 0 & $<500$ & 11523 & 0 & $<500$ & 0 & 0 & $<500$ & 0 & 0 & PMD & $\mathrm{mPD}$ & 133 \\
\hline & $\mathrm{Nab}$ & 256 & & & & & 4096 & & & & & & & \\
\hline \multirow[t]{2}{*}{$\mathrm{I} 347$} & Virus & 0 & $<500$ & 0 & 0 & $<500$ & 0 & 0 & $<500$ & & & & & 106 \\
\hline & $\mathrm{Nab}$ & 64 & & & 4096 & & & & & & & & & \\
\hline R319 & Virus & 0 & 0 & 0 & 0 & 0 & & 0 & $<500$ & & & $\begin{array}{c}\text { PMR } \\
(-49 \%)\end{array}$ & $\mathrm{mPR}$ & 332 \\
\hline R342 & Virus & 0 & $<500$ & & & $<500$ & & & & & & & $\mathrm{mPD}$ & 76 \\
\hline \multirow[t]{2}{*}{ R356 } & Virus & 0 & $<500$ & & $<500$ & 876 & & & $<500$ & & & & $\mathrm{mPR}$ & 102 \\
\hline & $\mathrm{NAb}$ & 1 & & & & & & & 1024 & & & & & \\
\hline \multirow[t]{2}{*}{ S352 } & Virus & 0 & 0 & & 0 & $<500$ & 0 & 0 & 0 & & 0 & $\begin{array}{l}\text { SMD } \\
(+6 \%) \\
\end{array}$ & & 112 \\
\hline & $\mathrm{NAb}$ & & 16 & & & & & 1024 & & & & & & \\
\hline \multirow[t]{2}{*}{ S354 } & Virus & 0 & 789 & & 0 & 0 & & & $<500$ & & 0 & $\begin{array}{c}\text { CMR } \\
(-76 \%)^{\mathrm{a}} \\
\end{array}$ & & $1009 *$ \\
\hline & $\mathrm{NAb}$ & 256 & & & & & & & 4096 & & 4096 & & & \\
\hline
\end{tabular}

$\mathrm{MMR}=$ minor metabolic response, $\mathrm{SMD}=$ stable metabolic disease, $\mathrm{PMD}=$ progressive metabolic disease, $\mathrm{PMR}=$ partial metabolic response, $\mathrm{CMR}=$ complete metabolic response.

${ }^{a}$ complete metabolic response, $76 \%$ reduction in tumor size $*$ patient alive on $14.1 .2014 \mathrm{mPR}=$ marker partial response, $\mathrm{mSD}=$ marker stable disease, $\mathrm{mCR}=$ marker complete response, $\mathrm{mMR}=$ marker minor response, $\mathrm{mPD}=$ marker progressive disease. 
increase in serum antibody titers (titers between 200 and 3000). Titers stayed elevated with a slow decreasing trend in some patients, during the months following treatment (Figure S2A). Further, ascites samples from patient O314 were analyzed for anti-hexon antibody titers at baseline and 3 weeks after treatment and antibody levels increased from $57 \mathrm{U} / \mathrm{ml}$ to $509 \mathrm{U} / \mathrm{ml}$ (Figure S2B). Titers of antibodies attached to ascites cells were also evaluated, and they increased from 42 to $471 \mathrm{U} / 100 \mathrm{mg}$ protein. The latter may indicate virus replication, and subsequent antibody binding to cells present in ascites, a typical location of ovarian cancer cells.

\section{PET CT and tumor markers}

All patients had progressing tumors prior to treatment. 6 patients could be assessed with PET-CT (modified PERCIST criteria [36]) (Table 2). Response was typically assessed 3-4 weeks after the last virus injection; typically 3 injections were given 3 weeks apart. R319 had partial metabolic response (PMR, $49 \%$ reduction in metabolic activity) in the injected liver tumor and a complete metabolic response in a non-injected mediastinal tumor (Figure 4a), S354 had a complete metabolic response (CMR, Figure $4 \mathrm{~b}$ and Figure S3), O340 had a minor metabolic response (MMR), C312 and S352 had stable metabolic disease (SMD) and H344 had progressive metabolic disease (PMD). Therefore, the radiological disease control rate (stable disease or better) was $83 \%$ while the PET response rate (including MMR) was 50\%.

With regard to tumor markers, assessed for patients who had elevated markers at baseline, 3/10 patients had reduction of marker levels (O314, O337, O351), 2/10 had initial reduction and subsequent elevation of marker levels (R356, R319), 1 patient had initial elevation and subsequent reduction (O340) and 4/10 had elevation of marker levels (H344, C312, R342, H192, Figure S4). Thus, overall, 6/10 patients had some indication of possible treatment benefits, as measured by tumor markers in serum. R319, O340, H344 and C312 were evaluated also with PET-CT. While R319 and O340 had partial and minor metabolic responses, $\mathrm{C} 312$ had only stabilization (and in fact a 23\% increase in SUVmax, fulfilling criteria of SMD) and H344 had metabolic progression. Thus, there was rather good correlation between PET response and tumor marker data.

Overall, with regard to tumor marker or radiological responses, signs of antitumor efficacy were seen in 9/12 evaluable patients $(75 \%)$. These patients lived a median of 135 days while the median survival of the other three was 80 days. In patient 1347 treatment efficacy could not be evaluated with any method. Thus, in an overall intent-totreat analysis, there was some evidence of efficacy in 9/13 patients $(69 \%)$. Overall survival of all patients is shown in (Figure S5).

\section{Changes in peripheral blood T-cell activity are seen in patients treated with Ad5/3-E2F- $\Delta 24-$ GMCSF}

Peripheral blood mononuclear cells (PBMCs) were collected and pulsed with Ad5 penton peptide or with tumor associated peptide pools (Survivin, CEA + NYESO-1 or c-myc + SSX2). IFN- $\gamma$ production was then analyzed with ELISPOT to evaluate the number of antitumor and anti-viral T-cells (Figure 2). Interestingly, in most patients the behavior of anti-tumor cells closely resembled changes seen in anti-viral cells; if the latter increased, also the former did and vice versa. In 8 patients (R319, O314, C312, I347, O337, R356, H344, S352), there was an increase (considered as a higher than at baseline at any timepoint) in one or more classes of antitumor T-cells, while in 3 patients (O340, O351, S354) there was a decrease. For anti-viral T-cells, the respective numbers were also 8 and 3 (increase: R319, O314, C312, I347, O337, R356, O340, H344, decrease: O351, S352, $\mathrm{S} 354)$ and thus there was concordance in $9 / 11(82 \%)$ patients between anti-tumor T-cells and anti-viral T-cells (the discordant patients were $\mathrm{O} 340$ and S352). This finding may suggest that in humans, anti-viral response corresponds and may contribute to anti-tumor response through epitope spreading and reduction of tumorassociated immunological tolerance. [17] However, as proposed before $[17,37]$, there was no correlation between changes in T-cells and clinical indicators of treatment efficacy, as a decrease of T-cells in blood might indicate trafficking to tumors [17, 38]. T-cell anergy [38] (no induction, no trafficking) was not seen in any patients.

\section{Antibodies against tumor associated antigens decrease in responding patients}

Antibodies against tumor associated antigens are frequently elevated in cancer patients even at early stages of the disease, indicating recognition of tumor epitopes by the immune system [39]. Interestingly, a body of data from the cancer vaccine field indicates that antitumor antibodies can be indicative of treatment efficacy. Specifically, a decrease in anti-tumor antibodies can indicate anti-tumor response and an increase can indicate lack of response [40]. For example, antibodies against NY-ESO-1 were shown to disappear from serum of patients that are in remission [41].

In our patients, antibodies against CEA, NY-ESO-1, survivin or MUC-1 frequently decreased in patients with signs of anti-tumor efficacy (Figure 3A). For example, patient $\mathrm{O} 314$ seemed to benefit from treatment as she had a partial response in CA12-5. She had a decrease in all four anti-tumor antibodies measured in her blood. R319 had a partial metabolic response in PET and a partial tumor marker response, and decrease in 3/4 antitumor antibodies in her blood. R356 had a partial marker 


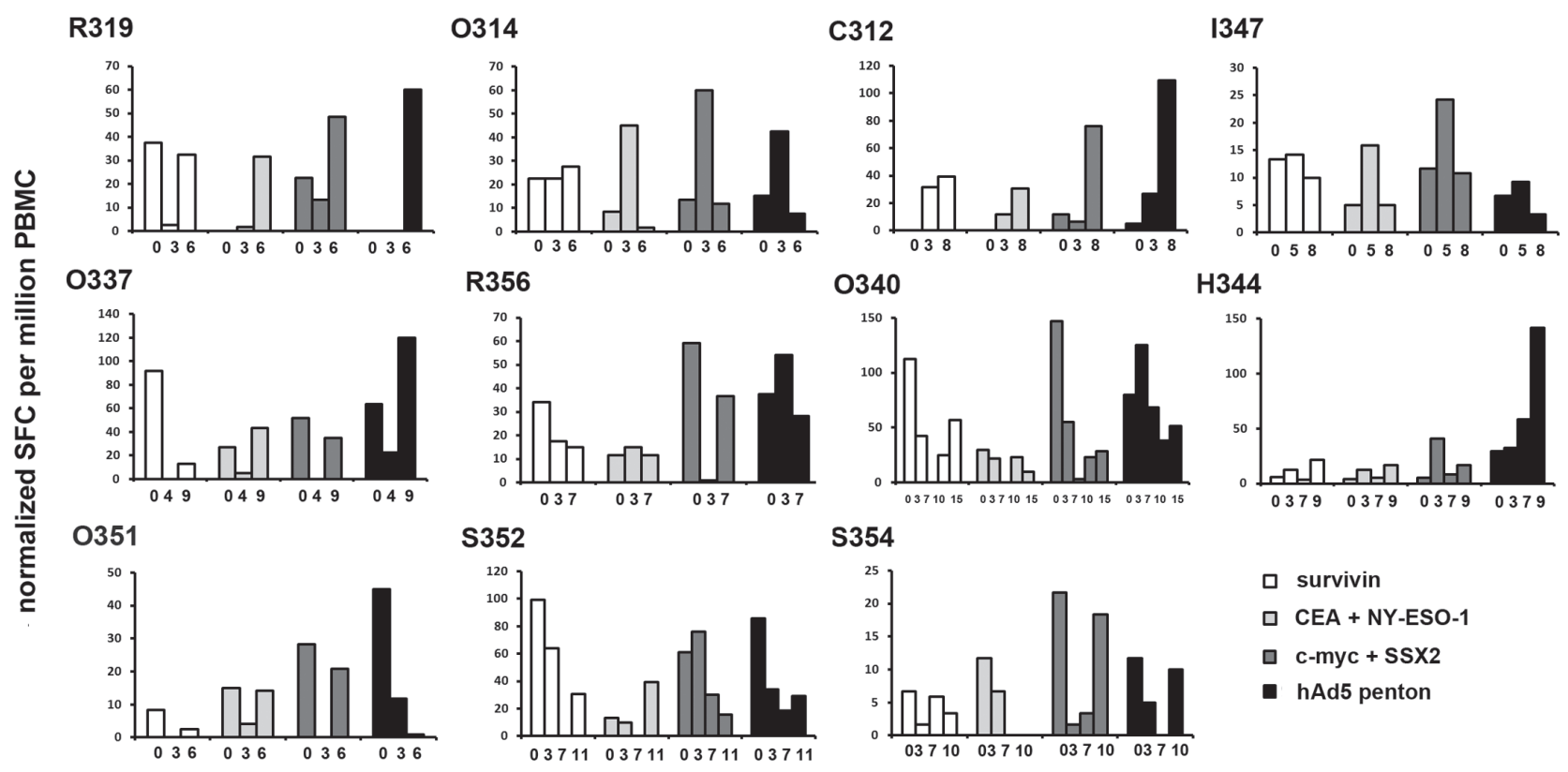

weeks after 1st treatment

Figure 2: Ad5/3-E2F-A24-GMCSF elicited $T$ cell responses against adenovirus and tumor epitopes in cancer patients. PBMCs harvested from patients treated with Ad5/3-E2F- $\Delta 24-G M C S F$ were analyzed by IFN-gamma ELISPOT upon stimulation with a mix of peptide from Adenovirus 5 and mixes of peptides from tumor antigens CEA and NY-ESO-1 (pool1), c-myc and SSX2 (pool2) and Survivin alone. Bars represent the frequency of IFN-gamma producing peptide specific PBMCs per million cells. SFC, Spot Forming Colonies.

response and a decrease in all three anti-tumor antibodies. Likewise, there seemed to be correlation between clinical benefits and anti-tumor antibodies in C312 and O351. In contrast, in patients $\mathrm{H} 192$ and H344, there were no signs of clinical benefits, and in both cases anti-tumor antibodies increased. Overall, a significant $(P=0.02)$ correlation between anti-tumor antibodies and clinical signs of benefit from treatment was seen.

In one case (O314), anti-tumor antibody levels in blood could be compared to anti-tumor antibody levels in ascites and cells present in ascites (which typically contains tumor cells). Interestingly, there was close correlation between all three compartments, suggesting that systemic measurement of antibody levels could be a reliable indicator of local events at the tumor (Figure 3B), which is compatible with the long half-life and systemic dissemination of antibodies in general.

\section{Biopsies}

Patient C322 underwent surgery 3 weeks after treatment with Ad5/3-E2F- 24 -GMCSF, which allowed immunohistochemical analysis of the operated tumor. More CD8+ cytotoxic T-cells (brown) were seen in tumor than in normal tissue (Figure 4c).

Biopsies before the first virus treatment and three weeks after the third virus treatment were available from patients $\mathrm{O} 340$ and R356 (Figure 4d). Before treatment both of the core needle biopsies taken from patient O340 and R356 showed only tumor tissue. In contrast, after treatment biopsies showed only a proportion of tumor tissue (O340 circa 15\%, R356 circa 75\% tumor cells). Assuming similar skills by the radiologist on both occasions, one explanation for this finding would be treatment mediated anti-tumor effects.

Immunohistochemical stainings for various immunological cell types were performed (Figure 4d). Interestingly with patient $\mathrm{O} 340$ a clear increase in the proportion of mature T-cells (CD3) (x34), T-helper cells (CD4) (x9) and cytotoxic T-cells (CD8) (x26) is seen, while CD11c-positive cells, B-cells (CD19) and CD25-positive cells (including eg. regulatory T-cells) virtually disappeared from the tumor. Concurrently the number of monocytic macrophages (CD68 and CD163) increased (x10 and $\mathrm{x} 8$ respectively). This patient seemed to respond to treatment as measured by PET-CT (MMR), markers (mCR), long survival (890d) (Table 2) and decrease in anti-Ca15-3 antibodies (Figure 3). Moreover, a drastic decrease in tumor antigen specific T-cells was observed in blood preceding the biopsy (Figure 2). As proposed [17], a decrease in anti-tumor T-cells in blood is compatible with trafficking of those cells to the tumor, a notion supported by evidence in this case, as CD8+ cells increased 26-fold in the tumor.

Less dramatic changes in cell density were also seen in the immunohistochemical stainings of patient 
A

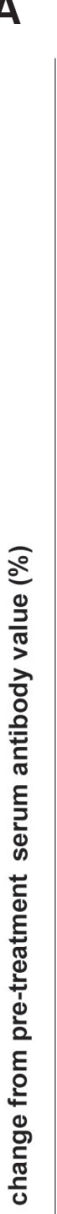
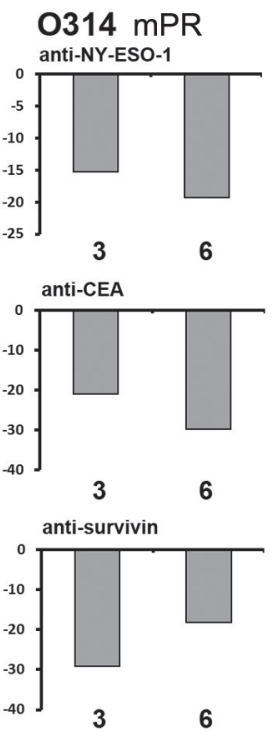

anti-Ca15-3

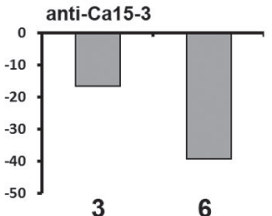

$$
\text { H192 mPD }
$$

anti-NY-ESO-1
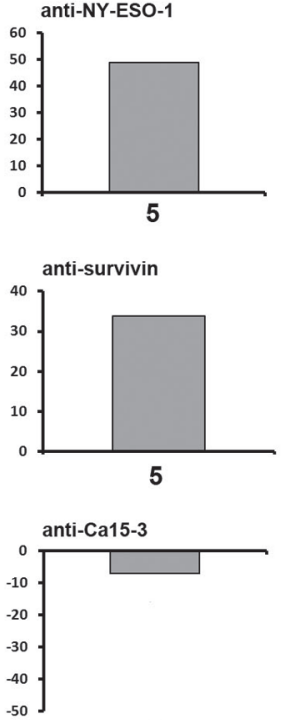

R319 PMR, mPR
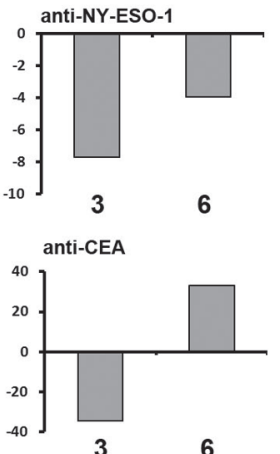

ti-survivin
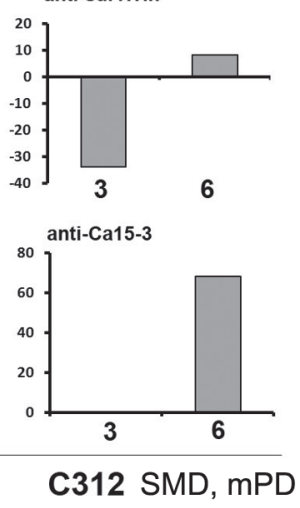
anti-NY-ESO-1
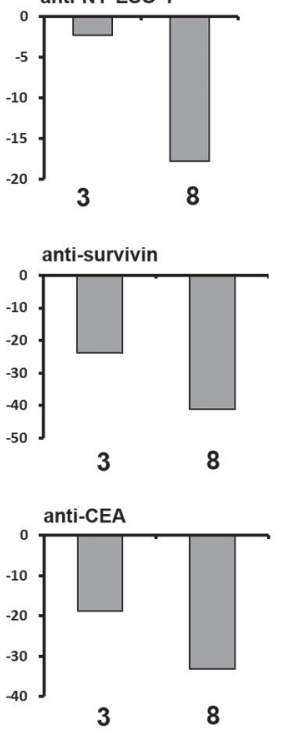

weeks after first treatment
R356 mPR

anti-CEA

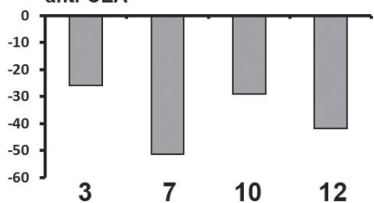

anti-survivin
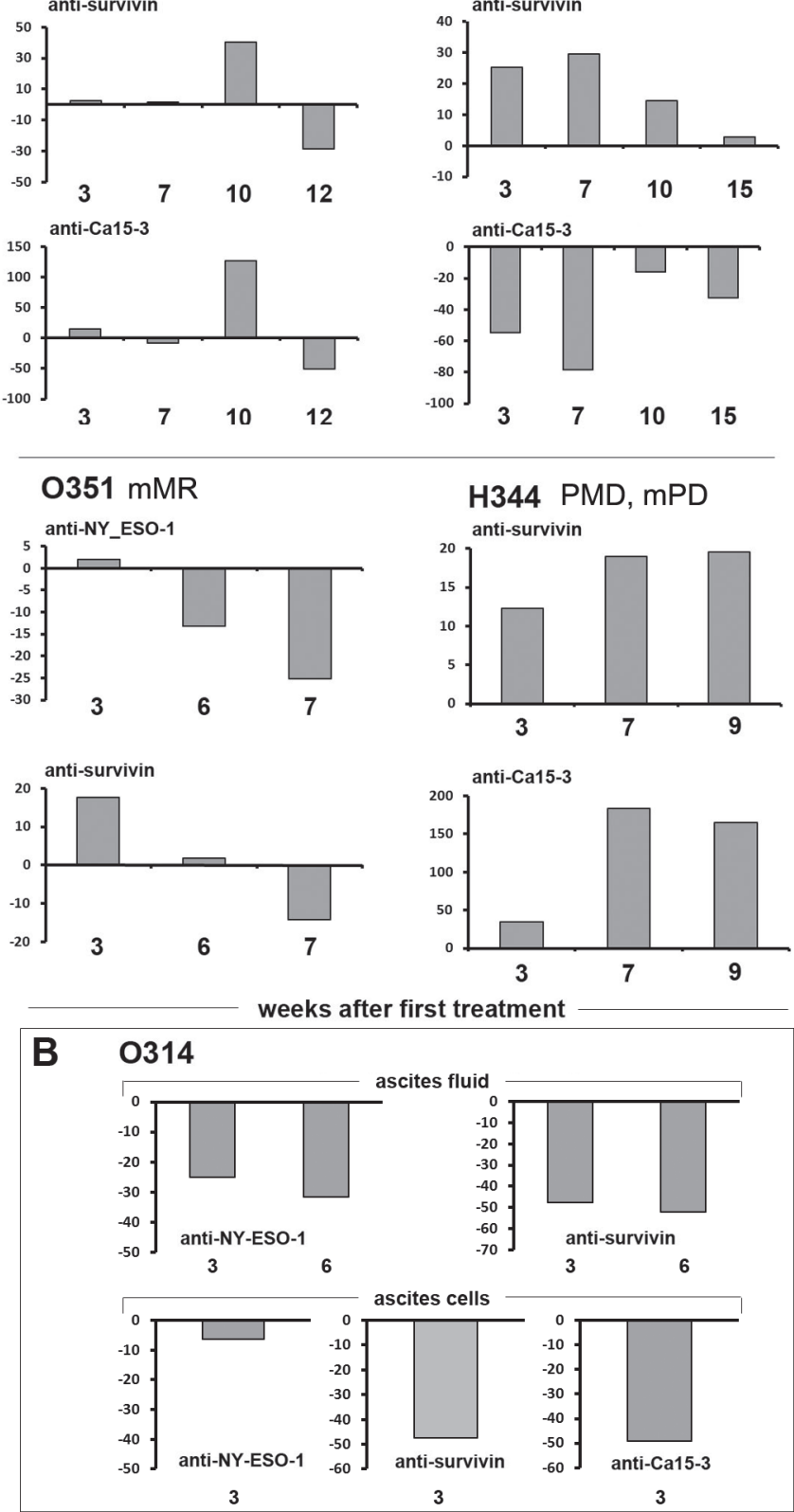

Figure 3: (A) Antibodies against tumor associated antigens (TAAs) NY-ESO-1, CA-15-3, CEA and survivin were analyzed from patient serum (A) and ascites fluid and cells of patient $\mathrm{O314}$ (B) before and after viral treatment, and the data is presented as proportional change (\%) of antibody levels (as estimated by ELISA absorbance units) from pre-treatment values. (A) Treatment often resulted in decrease of elevated levels of antibodies against TAAs in patients that showed a concomitant response in PET-CT or decrease in marker levels (patients O314, R356, R319, O340, C312, O351). Patients H192 and H344 did not show any benefit in PET-CT or markers and increasing levels of antibodies against TAAs were noted. (B) Malignant ascites (resulting from peritoneal tumor masses) was removed from the peritoneal cavity of patient $\mathrm{O} 314$ before and 19 and 40 days after virus administration. As with the serum samples decreasing amounts of antibodies against TAA were noted. 

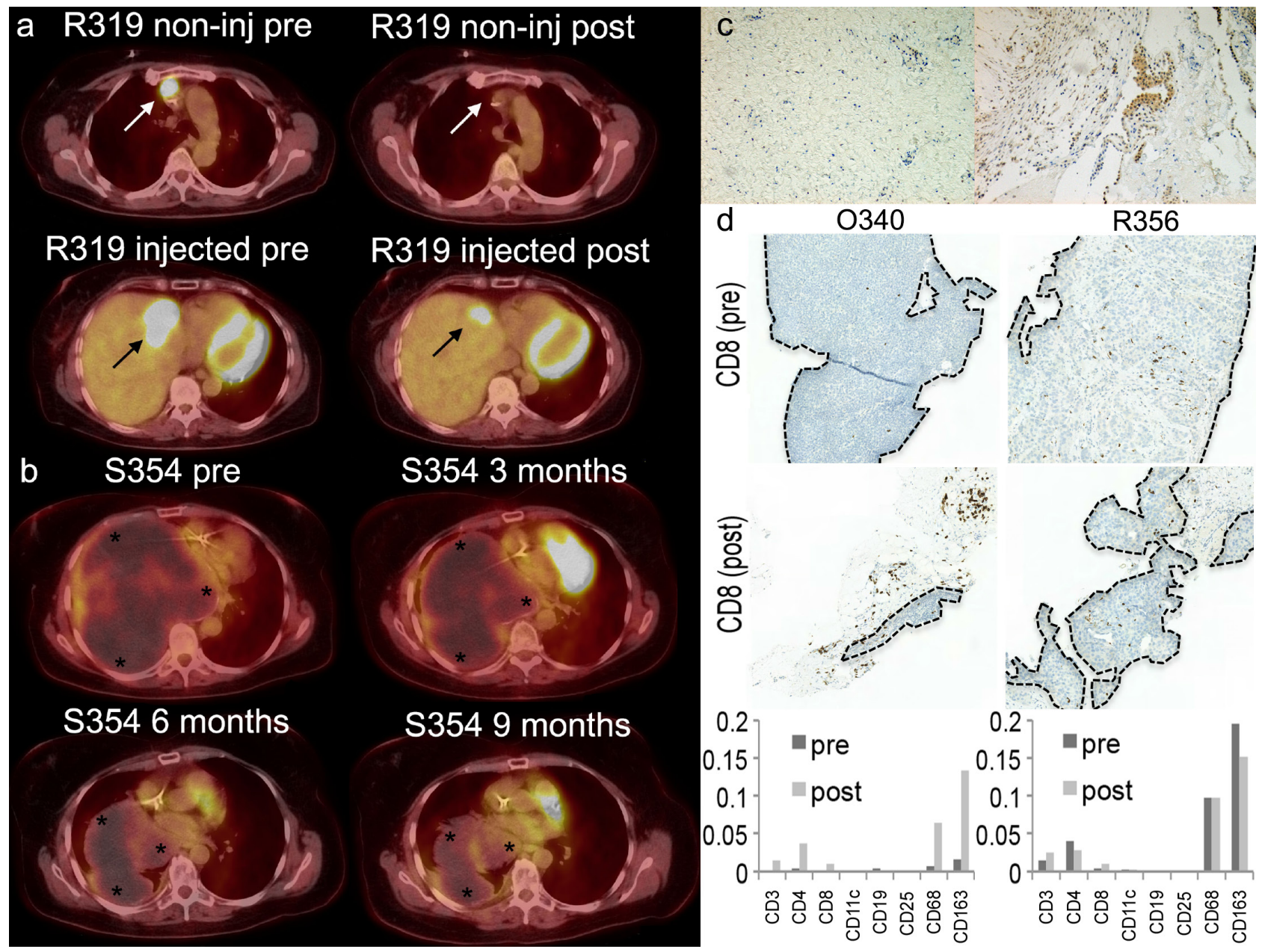

Figure 4: Positron emission tomography-computed tomography (PET-CT) fusion images from patients R319 (a) and S354 (b). (a) A non-injected mediastinal lesion disappeared after treatment (white arrows). 49\% reduction in metabolic activity of an injected lesion in the liver (black arrow). (b) A total of 76\% reduction is seen in tumor (stars) volume of patient S354. A 46\% reduction in tumor volume was seen at 3 months, $76 \%$ reduction at 6 months and a stable situation at 9 months after the first treatment. Patient S354 was given 3 treatments every 3 weeks and after that a continuation treatment scheme was started with treatments given every 3 weeks. (c) Patient C322 was operated 3 weeks after treatment with Ad5/3-E2F- $\Delta 24-G M C S F$. More CD8+ cytotoxic T-cells (brown) were seen in tumor (right panel) than normal tissue (left panel) collected during the operation. (d) Biopsies before the first virus treatment and three weeks after the third virus treatment were available from patients O340 and R356. Immunohistochemical CD8 staining (dark brown dots) is shown. The area of the tumor was drawn by a pathologist and marked by a dotted line in the figure. Amount of stained cells in the tumor area divided by the area containing tumor is shown in the graph below. Large amounts of immunological cells seem to arrive to the tumor after the treatment. Also large quantities are seen around the tumor rim. Especially profound is the T-cell infiltration within the tumor of patient O340 that had a lower quantity of immunological cells at baseline.

R356 (up to $\mathrm{x} 3$ ). A partial response (mPR) in markers was observed but the patient survived only 102 days (Table 2). Some changes were seen in blood T-cells and anti-tumor antibodies (Figure 2-3). Taken together, the data suggest that in this patient the anti-tumor effect was transient, perhaps chiefly mediated by oncolysis, since a clear immunological change did not occur at the tumor, as estimated by immunohistochemistry of the biopsy.

In these two cases with biopsy material available, we also analysed RNA expression patterns and predicted underlying biological functions by using Ingenuity pathway analysis software (Ingenuity System Inc, USA) (Figure S6). Thousands of pathways were analyzed, but only 25 (O340) and 18 (R356) were found significantly altered by treatment. Interestingly, nine of these pathways were the same in both patients, possibly hinting at mechanism of action. Noteworthy were the three retinoid $\mathrm{X}$ receptor (RXR) pathways, with known associations to immunology, particularly $\mathrm{CD} 8+$ and regulatory T-cell responses [42, 43]. These and "acute phase response signaling" pathways seem to suggest that treatment with Ad5/3-E2F- $224-G M C S F$ induces immunological activity. 


\section{DISCUSSION}

Based on the preclinical and clinical findings reported here, Ad5/3-E2F- $\triangle 24-G M C S F$ seems to function as designed: The Ad3 fiber knob enables efficient transduction of tumor cells while the E2F1 promoter and 24bp deletion provide excellent tumor selectivity (as demonstrated by lack of replication in hamster livers in vivo and human hepatocytes ex vivo). Functional GMCSF is produced following cellular entry.

Interestingly, as reported before with this HapT1 Syrian hamster tumor model with a similar although distinct virus [16] it seems that after the virus has entered the tumor it takes 3-4 days for the viral DNA copy number to peak after which a much lower amount of virus DNA is present in the tumor, probably because infected cells were killed either due to oncolysis or immunological eradication of infected cells. Seemingly in support of the former, the amount of viral DNA again starts to increase after dipping, which is compatible with a second wave of viral replication (Figure 1B bottom). However, lack of productive oncolysis in vitro with this cell line (Figure S1) suggests in fact that in vivo killing of cells filled with virus genomes and other components is in fact immunological. Our conclusions are that a) Ad5/3 is not oncolytic on Syrian hamster HapT1 cells in vitro (although the virus is oncolytic in some other Syrian hamster cell lines [28]), b) DNA replication is nevertheless seen in vivo, c) in vivo efficacy is caused mostly by immune response against the virus and/or stimulated by GMCSF. It seems unlikely that the virus would be oncolytic in vivo but not in vitro and thus we believe the qPCR result merely indicates DNA replication, not productive oncolysis, thus pin-pointing the block in permissivity between genome replication and lysis of the cell. The waves of DNA replication seen by qPCR must therefore reflect GMCSF stimulated immunological clearance of cells with a high content of adenoviral components.

While the design of this virus might facilitate intravenous administration we have not found a good animal model to test this. Syrian hamsters are technically challenging (fur, thick skin, lacking tail veins) with regard to an intravenous route and mouse tissues are nonpermissive for human adenovirus [44]. Variance in cell killing with serotype 5 wild type compared to our fiber modified $5 / 3$ virus in different cell lines (Figure 1C) might be due to the relative expression of the main $\mathrm{Ad} 5$ receptor coxsackie and adenovirus receptor versus the presence of Ad3 receptors such as desmoglein 2 as published [45-47].

Treatments were safe and many patients with variable types of solid cancers refractory to other therapies seemed to show signs of efficacy when evaluated by PET$\mathrm{CT}$ or by tumor markers. PET-CT was chosen as the imaging method as we believe the immune reaction caused by treatment results in tumor swelling which restricts the utility of size based evaluation criteria [36].
No virus DNA was detected in blood after the 2nd and 3rd injections, suggesting tight restriction of oncolysis to the tumors, or less replication than after the 1st cycle, or both. Interestingly, as reported with preclinical data [28] we noted disappearance of a non-injected tumor with patient R319 (Figure 4a). These findings are in support of the immunogenic mechanism being more important than pure oncolysis with regard to efficacy.

The patents had quite advanced tumors and they were heavily pretreated often with multiple lines of chemotherapy. Thus, when oncolytic virus treatment was stopped, some patients progressed rapidly, while some stabilized for extended times. It should be noted that most patients progressed off therapy, and thus eventual progression is not really evidence of lack of efficacy. However, as this was not a randomized trial we would hesitate to make any assumptions on efficacy over control patients. There are many well-known caveats in comparisons to historical controls and thus we believe a randomized setting is the appropriate approach for assessing effects on overall survival.

Interestingly, PET-CT and tumor marker responses and survival (Table 2) seemed to correlate with: 1) changes in the numbers and activity of circulating tumor reactive lymphocytes (Figure 2); 2) a decrease in anti-tumor antibodies in blood and ascites (Figure 3); 3) increases in CD3, CD4, CD8, CD68 and CD163 positive cells at the tumor (Figure 4).

Although these preliminary findings need to be confirmed in larger patient cohorts, immunohistochemical analysis of tumor biopsies suggested that immunological cells accumulated at tumors in patients responding to treatment while at the same time changes in cancer specific $\mathrm{T}$ cells in blood could be seen. This is compatible with previously published data and suggestive of trafficking of anti-tumor (and anti-viral) cells from blood into tumors [17, 46, 48-51]. Viral DNA was often detected in serum for several days after the first treatment while after subsequent treatments qPCR tended to be negative. Antibody titer against the virus increased exponentially while antibodies against tumor associated antigens decreased in responding patients, a finding proposed associated with anti-tumor efficacy $[40,41]$.

At baseline patient R356 had more (CD3 x33, CD4 x10, CD8 x9, CD11c x21, CD68 x15, CD163 x12) immunological cells in the tumor than patient $\mathrm{O} 340$ (Figure 4). After treatment the number of immunological cells increased more with O340 than with R356. Since both tumors were progressing at baseline, the data might indicate that the tumor of R356 featured stronger local immunosuppression (regulatory $\mathrm{T}$ cells etc.) to counterbalance the more prominent immunological infiltrate. For such patients virus induced immunological response might not be as useful, as the "gas pedal" is already fully engaged. For such tumors, "releasing the brake" might be more useful instead, alone or in 
combination with oncolytic immunotherapy. Thus new drugs such as PD-1 or anti-CTLA-4 antibodies combined to oncolytic viroterapy and/or T-cell therapy might lead to additive efficacy. It is clear that more patients are needed to study these phenomena in more detail and no definite conclusions can be made from a small number of biopsies, but on the other hand the data reported here may be the first available information on potentially important aspects of the technology.

In summary, Ad5/3-E2F-A24-GMCSF (CGTG-602) seems safe and effective for treatment of cancer. Clinical trials would be useful for demonstrating these aspects in more homogeneous patient populations, and for collecting more biological samples, to extend upon the preliminary analyses done here.

\section{MATERIALS AND METHODS}

\section{Viruses and cancer cell lines}

The construction of Ad5/3-E2F- $\Delta 24-\mathrm{GMCSF}$ is described in supplementary materials and methods. Ad5/3-424, Ad5/3lucI and Ad5/3-D24-GM-CSF have been described $[16,46,52]$. Cell lines used herein and their testing have been described $[18,53]$.

\section{Preclinical experiments}

In vitro assays. GMCSF dependent TF-1 erythroleukemia cells (Sigma Aldrich, St Louis, MO) were used to evaluate the functionality of GMCSF as described [16]. The results constitute of an average of 7 (mock 21, hGMCSF 11) samples, students $T$-test was used for statistics. The experiment showed that virusproduced hGMCSF was as bioactive as the commercial positive control (Recombinant human GM-CSF, 2ng/ml, PeproTech, 300-03) as reported [9, 28, 53-56]. Oncolytic potency was tested with MTS-assay performed 6 days (A549 and PC3-MM2) or 14 days (SKOV3.ip1) after virus incubation when $100 \%$ cell killing with the highest viral dose was observed [18]. Shown results are the average of four samples, error bars represent standard deviation. Students $T$-test was used for statistical analyses. Selectivity of virus replication in human primary hepatocytes is described in supplementary materials and methods. In vivo efficacy. Hamster pancreatic cancer tumors (HapT1) were grown subcutaneously in Syrian hamsters as described [9]. At 7 days tumors were injected with $3 \times 10^{8} \mathrm{VP} /$ tumor of either of Ad5/3-E2F- $\Delta 24-\mathrm{GMCSF}(n=6)$ or Ad5/3- $\Delta 24$ GMCSF $(n=5) 3$ times every 3 days. Further, 5 animals received cyclophosphamide intraperitoneally $(2 \mathrm{mg} /$ hamster) in combination with Ad5/3-E2F- $224-G M C S F$, 5 hamsters received cyclophosphamide only and 4 animals were mock-treated with intratumoral growth medium injections. Tumor volume was calculated by using a formula of $(0.5 \times$ length $) \times\left(\right.$ width $\left.^{2}\right)$.
In vivo tumor selectivity of $\mathrm{Ad} 5 / 3-\mathrm{E} 2 \mathrm{~F}-\Delta 24-$ GMCSF replication. After hamster HapT1 tumors reached approximately $0,5 \mathrm{~cm}$ in diameter (7 days), $3 \times 10^{8} \mathrm{VP}$ of Ad5/3-E2F- $224-G M C S F$ was injected intratumorally ( $n=8$ tumors/timepoint). Hamsters without tumors $(n=2$ hamsters/timepoint) were injected directly into the liver. Animals were killed and tumors or livers collected 0.5 , $24,48,72$ or 96 hours after virus injection, snap-frozen and stored at $-80^{\circ} \mathrm{C}$. Quantitative PCR has been described [16]. Activity of human GM-CSF in Syrian hamsters has been described previously [9, 28, 53-56].

\section{Patient treatments}

Patients were treated in an Advanced Therapy Access Program, regulated by EC/1394/2007 on advanced therapy medicinal products, amending Directive 2001/83/ EC and Regulation (EC) No 726/2004. According to EC/1394/2007 manufacturing of advanced therapy medicinal products shall be authorized by the competent authority of the Member State, which in Finland is the Finnish Medical Agency (FIMEA). FIMEA also requires reporting of adverse reactions. Virus administration was performed by ultrasound-guided intratumoral injection and circa one fifth of the dose was given intravenously during the first treatment only. The rationale for the latter relates to the generally low to average amount of neutralizing antibodies that are typically present at baseline, while after treatment antibodies often increase rapidly and thus the value of subsequent intravenous dosing is unknown. In any case, there is no need for subsequent intravenous injection because the tumor produces virus which is then shed into blood. Thus in subsequent injections the whole dose was given intratumorally. Most patients were treated three times every three weeks. Doses of $1-10 \times 10^{11} \mathrm{VP}$ were used based on safety results previously published with Ad5/3- $224-G M C S F$, a related virus lacking the E2F1 promoter [57]. All patients exluding C332 received low dose cyclophosphamid for reduction of regulatory T-cells [58]. Patients H192, 344, I347, S352 and S354 received also low dose temozolomide for enhancement of autophagy during oncolysis [59]. Typically, cyclophosphamide was used throughout the treatments with a dose of $50 \mathrm{mg} /$ day while temozolomide was used 5-7 days before and/or 7-14 days after the treatment at $100 \mathrm{mg} /$ day. Neither approach is known to have anti-tumor activity on their own $[37,60]$. Written informed consent was obtained from all patients. Patients were monitored overnight at the clinic and then as outpatients for 28 days for adverse events. Adverse reactions were recorded according to Common Terminology for Adverse Events v3.0. Survival and late adverse events were followed ad infinitum. ATAP treatments are not a trial but an individualized treatment program. However, in a separate research project, collection and analysis of biopsies was approved by the HUCH operative ethics committee, and 
a separate informed consent procedure was employed to ensure separation of research from treatment (Dnro 368/13/03/02/2009). Other patient sample analyses are also approved by the local Ethics Committee (HUS 62/13/03/02/2013). Because many cancer patients have symptoms due to disease, preexisting symptoms were not scored if they did not become worse. However, if the symptom became more severe, e.g., pretreatment grade 1 changed to grade 2 after treatment, it was scored as grade 2 . The neutralizing antibody assay [61] and the determination of virus genomes in blood [16] are previously published. Interferon gamma ELISPOT is described [17], all results were compared to cells spontaneously producing the cytokine, i.e. PBMCs without stimulation. For detail on the immunohistocehmical stainings, tumor biopsies and their quantitation please refer to supplementary materials and methods.

\section{FINANCIAL SUPPORT}

National Graduate School of Clinical Investigation, European Research Council, ASCO Foundation, HUCH Research Funds (EVO), Sigrid Juselius Foundation, Academy of Finland, Biocentrum Helsinki, Biocenter Finland, Finnish Cancer Organizations, University of Helsinki. Conflict of interest: O.H. and A.H. are shareholders in Oncos Therapeutics Ltd and TILT Biotherapeutics Ltd. A.H. is an employee of TILT Biotherapeutics Ltd.

\section{REFERENCES}

1. Eager RM, Nemunaitis J. Clinical development directions in oncolytic viral therapy. Cancer gene therapy. 2011; 18:305-317.

2. Sinkovics J, Horvath J. New developments in the virus therapy of cancer: a historical review. Intervirology. 1993; 36:193-214.

3. Toth K, Dhar D, Wold WS. Oncolytic (replicationcompetent) adenoviruses as anticancer agents. Expert opinion on biological therapy. 2010; 10:353-368.

4. Hemminki $\mathrm{OH}, \mathrm{A}$. Oncolytic adenoviruses in the treatment of cancer in humans In: Lattime SGaEC, ed. Gene Therapy of Cancer: Elsevier/Academic Press 2014.

5. Xia ZJ CJ, Zhang L, Jiang WQ, Guan ZZ, Liu JW, Zhang Y, $\mathrm{Hu} \mathrm{XH}, \mathrm{Wu}$ GH, Wang HQ, Chen ZC, Chen JC, Zhou QH, Lu JW, Fan QX, Huang JJ, Zheng X. Phase III randomized clinical trial of intratumoral injection of E1B gene-deleted adenovirus (H101) combined with cisplatin-based chemotherapy in treating squamous cell cancer of head and neck or esophagus. Ai Zheng Dec 2004; 23:1666-1670.

6. Robert Hans Ingemar Andtbacka FAC, Amatruda Thomas, Senzer Neil N., Chesney Jason, Delman Keith, A, Spitler Lynn, E, Puzanov Igor, Doleman Susan, Ye Yining, Vanderwalde Ari, M, Coffin Robert, Kaufman Howard. OPTiM: A randomized phase III trial of talimogene laherparepvec (T-VEC) versus subcutaneous (SC) granulocyte-macrophage colonystimulating factor (GM-CSF) for the treatment (tx) of unresected stage IIIB/C and IV melanoma. Journal of Clinical Oncology, 2013 ASCO Annual Meeting Abstracts 2013; 31:S18. 2013: LBA9008.

7. Cerullo V, Seiler MP, Mane V, Brunetti-Pierri N, Clarke C, Bertin TK, Rodgers JR, Lee B. Toll-like receptor 9 triggers an innate immune response to helper-dependent adenoviral vectors. Mol Ther. 2007; 15:378-385.

8. Tuve S, Liu Y, Tragoolpua K, Jacobs JD, Yumul RC, Li ZY, Strauss R, Hellstrom KE, Disis ML, Roffler S, Lieber A. In situ adenovirus vaccination engages T effector cells against cancer. Vaccine. 2009; 27:4225-4239.

9. Cerullo V, Pesonen S, Diaconu I, Escutenaire S, Arstila PT, Ugolini M, Nokisalmi P, Raki M, Laasonen L, Sarkioja M, Rajecki M, Kangasniemi L, Guse K, Helminen A, Ahtiainen L, Ristimaki A, et al. Oncolytic adenovirus coding for granulocyte macrophage colony-stimulating factor induces antitumoral immunity in cancer patients. Cancer Res. 2010; 70:4297-4309.

10. Cerullo V, Diaconu I, Romano V, Hirvinen M, Ugolini M, Escutenaire S, Holm SL, Kipar A, Kanerva A, Hemminki A. An oncolytic adenovirus enhanced for toll-like receptor 9 stimulation increases antitumor immune responses and tumor clearance. Molecular therapy: the journal of the American Society of Gene Therapy. 2012; 20:2076-2086.

11. Schubert U, Anton LC, Gibbs J, Norbury CC, Yewdell JW, Bennink JR. Rapid degradation of a large fraction of newly synthesized proteins by proteasomes. Nature. 2000; 404:770-774.

12. Chen YT, Scanlan MJ, Sahin U, Tureci O, Gure AO, Tsang S, Williamson B, Stockert E, Pfreundschuh M, Old LJ. A testicular antigen aberrantly expressed in human cancers detected by autologous antibody screening. Proc Natl Acad Sci U S A. 1997; 94:1914-1918.

13. von Mensdorff-Pouilly S, Petrakou E, Kenemans P, van Uffelen K, Verstraeten AA, Snijdewint FG, van Kamp GJ, Schol DJ, Reis CA, Price MR, Livingston PO, Hilgers J. Reactivity of natural and induced human antibodies to MUC1 mucin with MUC1 peptides and n-acetylgalactosamine (GalNAc) peptides. Int J Cancer. 2000; 86:702-712.

14. Bergelson JM, Cunningham JA, Droguett G, KurtJones EA, Krithivas A, Hong JS, Horwitz MS, Crowell RL, Finberg RW. Isolation of a common receptor for Coxsackie B viruses and adenoviruses 2 and 5. Science. 1997; 275:1320-1323.

15. Kim M, Zinn KR, Barnett BG, Sumerel LA, Krasnykh V, Curiel DT, Douglas JT. The therapeutic efficacy of adenoviral vectors for cancer gene therapy is limited by a low level of primary adenovirus receptors on tumour cells. Eur J Cancer. 2002; 38:1917-1926.

16. Koski A, Kangasniemi L, Escutenaire S, Pesonen S, Cerullo V, Diaconu I, Nokisalmi P, Raki M, Rajecki M, Guse K, Ranki T, Oksanen M, Holm SL, Haavisto E, Karioja-Kallio A, Laasonen L, et al. Treatment of cancer 
patients with a serotype $5 / 3$ chimeric oncolytic adenovirus expressing GMCSF. Molecular therapy: the journal of the American Society of Gene Therapy. 2010; 18:1874-1884.

17. Kanerva A, Nokisalmi P, Diaconu I, Koski A, Cerullo V, Liikanen I, Tahtinen S, Oksanen M, Heiskanen R, Pesonen S, Joensuu T, Alanko T, Partanen K, Laasonen L, Kairemo K, Kangasniemi L, et al. Antiviral and antitumor T-cell immunity in patients treated with GM-CSF-coding oncolytic adenovirus. Clinical cancer research: an official journal of the American Association for Cancer Research. 2013; 19:2734-2744.

18. Hemminki O, Bauerschmitz G, Hemmi S, Lavilla-Alonso S, Diaconu I, Guse K, Koski A, Desmond RA, Lappalainen M, Kanerva A, Cerullo V, Pesonen S, Hemminki A. Oncolytic adenovirus based on serotype 3. Cancer gene therapy. 2011; 18:288-296.

19. Hemminki O, Diaconu I, Cerullo V, Pesonen SK, Kanerva A, Joensuu T, Kairemo K, Laasonen L, Partanen K, Kangasniemi L, Lieber A, Pesonen S, Hemminki A. Ad3hTERT-E1A, a fully serotype 3 oncolytic adenovirus, in patients with chemotherapy refractory cancer. Molecular therapy: the journal of the American Society of Gene Therapy. 2012; 20:1821-1830.

20. Pesonen S, Diaconu I, Cerullo V, Escutenaire S, Raki M, Kangasniemi L, Nokisalmi P, Dotti G, Guse K, Laasonen L, Partanen K, Karli E, Haavisto E, Oksanen M, KariojaKallio A, Hannuksela P, et al. Integrin targeted oncolytic adenoviruses Ad5-D24-RGD and Ad5-RGD-D24-GMCSF for treatment of patients with advanced chemotherapy refractory solid tumors. International journal of cancer Journal international du cancer. 2012; 130:1937-1947.

21. Bauerschmitz GJ, Guse K, Kanerva A, Menzel A, Herrmann I, Desmond RA, Yamamoto M, Nettelbeck DM, Hakkarainen T, Dall P, Curiel DT, Hemminki A. Tripletargeted oncolytic adenoviruses featuring the cox 2 promoter, E1A transcomplementation, and serotype chimerism for enhanced selectivity for ovarian cancer cells. Molecular therapy: the journal of the American Society of Gene Therapy. 2006; 14:164-174.

22. Fueyo J, Gomez-Manzano C, Alemany R, Lee PS, McDonnell TJ, Mitlianga P, Shi YX, Levin VA, Yung WK, Kyritsis AP. A mutant oncolytic adenovirus targeting the $\mathrm{Rb}$ pathway produces anti-glioma effect in vivo. Oncogene. 2000; 19:2-12.

23. Alonso MM, Alemany R, Fueyo J, Gomez-Manzano C. E2F1 in gliomas: a paradigm of oncogene addiction. Cancer letters. 2008; 263:157-163.

24. Hanahan D, Weinberg RA. The hallmarks of cancer. Cell. 2000; 100:57-70.

25. Johnson L, Shen A, Boyle L, Kunich J, Pandey K, Lemmon M, Hermiston T, Giedlin M, McCormick F, Fattaey A. Selectively replicating adenoviruses targeting deregulated E2F activity are potent, systemic antitumor agents. Cancer Cell. 2002; 1:325-337.
26. Senzer NN, Kaufman HL, Amatruda T, Nemunaitis M, Reid T, Daniels G, Gonzalez R, Glaspy J, Whitman E, Harrington K, Goldsweig H, Marshall T, Love C, Coffin R, Nemunaitis JJ. Phase II clinical trial of a granulocytemacrophage colony-stimulating factor-encoding, secondgeneration oncolytic herpesvirus in patients with unresectable metastatic melanoma. Journal of clinical oncology: official journal of the American Society of Clinical Oncology. 2009; 27:5763-5771.

27. Hemminki O, Immonen $\mathrm{R}$, Narvainen $\mathrm{J}$, Kipar $\mathrm{A}$, Paasonen J, Jokivarsi KT, Yli-Ollila H, Soininen P, Partanen K, Joensuu T, Parvianen S, Pesonen SK, Koski A, Vaha-Koskela M, Cerullo V, Pesonen S, et al. In vivo magnetic resonance imaging and spectroscopy identifies oncolytic adenovirus responders. International journal of cancer Journal international du cancer. 2014; 134:2878-2890.

28. Bramante S, Koski A, Kipar A, Diaconu I, Liikanen I, Hemminki O, Vassilev L, Parviainen S, Cerullo V, Pesonen SK, Oksanen M, Heiskanen R, RouvinenLagerstrom N, Merisalo-Soikkeli M, Hakonen T, Joensuu $\mathrm{T}$, et al. Serotype chimeric oncolytic adenovirus coding for GM-CSF for treatment of sarcoma in rodents and humans. International journal of cancer Journal international du cancer. 2014; 135:720-730.

29. Dias JD, Hemminki O, Diaconu I, Hirvinen M, Bonetti A, Guse K, Escutenaire S, Kanerva A, Pesonen S, Loskog A, Cerullo V, Hemminki A. Targeted cancer immunotherapy with oncolytic adenovirus coding for a fully human monoclonal antibody specific for CTLA-4. Gene therapy. 2012; 19:988-998.

30. Dhar D, Spencer JF, Toth K, Wold WS. Effect of preexisting immunity on oncolytic adenovirus vector INGN 007 antitumor efficacy in immunocompetent and immunosuppressed Syrian hamsters. Journal of virology. 2009; 83:2130-2139.

31. Diaconu I, Cerullo V, Escutenaire S, Kanerva A, Bauerschmitz GJ, Hernandez-Alcoceba R, Pesonen S, Hemminki A. Human adenovirus replication in immunocompetent Syrian hamsters can be attenuated with chlorpromazine or cidofovir. The journal of gene medicine. 2010; 12:435-445.

32. Bramante S, Koski A, Kipar A, Diaconu I, Liikanen I, Hemminki O, Vassilev L, Parviainen S, Cerullo V, Pesonen SK, Oksanen M, Heiskanen R, RouvinenLagerstrom N, Merisalo-Soikkeli M, Hakonen T, Joensuu T, et al. Serotype chimeric oncolytic adenovirus coding for GM-CSF for treatment of sarcoma in rodents and humans. International journal of cancer Journal international du cancer. 2013.

33. Hemminki A. Oncolytic immunotherapy: where are we clinically? Scientifica. 2014; 2014:862-925.

34. Hemminki A, Oksanen M, Merisalo-Soikkeli M. Oncolytic virotherapy trials-letter. Clinical cancer research: an official journal of the American Association for Cancer Research. 2013; 19:4541-4542. 
35. Hemminki A. Treatment of chemotherapy-refractory cancer in the advanced therapy access program. Molecular therapy: the journal of the American Society of Gene Therapy. 2012; 20:1654-1655.

36. Koski A, Ahtinen H, Liljenback H, Roivainen A, Koskela A, Oksanen M, Partanen K, Laasonen L, Kairemo K, Joensuu T, Hemminki A. [(18)F]-fluorodeoxyglucose positron emission tomography and computed tomography in response evaluation of oncolytic adenovirus treatments of patients with advanced cancer. Human gene therapy. 2013; 24:1029-1041.

37. Liikanen I, Ahtiainen L, Hirvinen ML, Bramante S, Cerullo V, Nokisalmi P, Hemminki O, Diaconu I, Pesonen S, Koski A, Kangasniemi L, Pesonen SK, Oksanen M, Laasonen L, Partanen K, Joensuu T, et al. Oncolytic adenovirus with temozolomide induces autophagy and antitumor immune responses in cancer patients. Molecular therapy: the journal of the American Society of Gene Therapy. 2013; 21:1212-1223.

38. Brahmer JR, Tykodi SS, Chow LQ, Hwu WJ, Topalian SL, Hwu P, Drake CG, Camacho LH, Kauh J, Odunsi K, Pitot HC, Hamid O, Bhatia S, Martins R, Eaton K, Chen S, et al. Safety and activity of anti-PD-L1 antibody in patients with advanced cancer. The New England journal of medicine. 2012; 366:2455-2465.

39. Reuschenbach M, von Knebel Doeberitz M, Wentzensen N. A systematic review of humoral immune responses against tumor antigens. Cancer immunology, immunotherapy: CII. 2009; 58:1535-1544.

40. Odunsi K, Matsuzaki J, Karbach J, Neumann A, MhawechFauceglia P, Miller A, Beck A, Morrison CD, Ritter G, Godoy H, Lele S, duPont N, Edwards R, Shrikant P, Old LJ, Gnjatic S, et al. Efficacy of vaccination with recombinant vaccinia and fowlpox vectors expressing NY-ESO-1 antigen in ovarian cancer and melanoma patients. Proceedings of the National Academy of Sciences of the United States of America. 2012; 109:5797-5802.

41. Rodolfo M, Luksch R, Stockert E, Chen YT, Collini P, Ranzani T, Lombardo C, Dalerba P, Rivoltini L, Arienti F, Fossati-Bellani F, Old LJ, Parmiani G, Castelli C. Antigenspecific immunity in neuroblastoma patients: antibody and T-cell recognition of NY-ESO-1 tumor antigen. Cancer Res. 2003; 63:6948-6955.

42. Hall JA, Grainger JR, Spencer SP, Belkaid Y. The role of retinoic acid in tolerance and immunity. Immunity. 2011; $35: 13-22$.

43. Takeuchi H, Yokota-Nakatsuma A, Ohoka Y, Kagechika H, Kato C, Song SY, Iwata M. Retinoid X receptor agonists modulate Foxp3 $(+)$ regulatory T cell and Th17 cell differentiation with differential dependence on retinoic acid receptor activation. J Immunol. 2013; 191:3725-3733.

44. Alemany R, Balague C, Curiel DT. Replicative adenoviruses for cancer therapy. Nature biotechnology. 2000; 18:723-727.
45. Sarkioja M, Kanerva A, Salo J, Kangasniemi L, Eriksson M, Raki M, Ranki T, Hakkarainen T, Hemminki A. Noninvasive imaging for evaluation of the systemic delivery of capsid-modified adenoviruses in an orthotopic model of advanced lung cancer. Cancer. 2006; 107:1578-1588.

46. Kanerva A, Mikheeva GV, Krasnykh V, Coolidge CJ, Lam JT, Mahasreshti PJ, Barker SD, Straughn M, Barnes MN, Alvarez RD, Hemminki A, Curiel DT. Targeting adenovirus to the serotype 3 receptor increases gene transfer efficiency to ovarian cancer cells. Clinical cancer research: an official journal of the American Association for Cancer Research. 2002; 8:275-280.

47. Wang H, Li ZY, Liu Y, Persson J, Beyer I, Moller T, Koyuncu D, Drescher MR, Strauss R, Zhang XB, Wahl JK. 3rd, Urban N, Drescher C, Hemminki A, Fender P, Lieber A. Desmoglein 2 is a receptor for adenovirus serotypes 3, 11 and 14. Nature medicine. 2011; 17:96-104.

48. Brahmer JR, Drake CG, Wollner I, Powderly JD, Picus J, Sharfman WH, Stankevich E, Pons A, Salay TM, McMiller TL, Gilson MM, Wang C, Selby M, Taube JM, Anders R, Chen L, et al. Phase I study of single-agent anti-programmed death-1 (MDX-1106) in refractory solid tumors: safety, clinical activity, pharmacodynamics, and immunologic correlates. Journal of clinical oncology: official journal of the American Society of Clinical Oncology. 2010; 28:3167-3175.

49. Pesonen S. HA, von Euler M, Vuolanto A, Backman C, Hakonen T, Alanko T. KK, Partanen K, Turkki R, Linder N, Lundin J, Ristimäki A, Dienel K. KM, Jäger E, Karbach J, Wahle C, Ranki T, Vassilev L, Juhila J. JT. Characterization of tumor-infiltrating lymphocytes following intratumoral administration of a chimeric adenovirus Ad5/3-D24GMCSF (ONCOS-102) for refractory cancer patients with solid tumors. CIMT. 2014; Mainz, Germany.

50. Ranki T. Induction of anti-tumor CD8+ T cells and prominent infiltration of lymphocytes with a Th1 polarizing signature to pleural mesothelioma tumor following intratumoral injection of ONCOS-102. CIMT. 2014; Mainz, Germany.

51. Vassilev L. Repeated intratumoral administration of ONCOS-102 leads to robust cellular and transcriptional immune activation at tumor site in an ovarian cancer patient. CIMT. 2014; Mainz, Germany.

52. Kanerva A, Zinn KR, Chaudhuri TR, Lam JT, Suzuki K, Uil TG, Hakkarainen T, Bauerschmitz GJ, Wang M, Liu B, Cao Z, Alvarez RD, Curiel DT, Hemminki A. Enhanced therapeutic efficacy for ovarian cancer with a serotype 3 receptor-targeted oncolytic adenovirus. Molecular therapy: the journal of the American Society of Gene Therapy. 2003; 8:449-458

53. Hemminki $\mathrm{O}$, Immonen $\mathrm{R}$, Narvainen $\mathrm{J}$, Kipar $\mathrm{A}$, Paasonen J, Jokivarsi KT, Yli-Ollila H, Soininen P, Partanen K, Joensuu T, Parvianen S, Pesonen SK, Koski A, Vaha-Koskela $\mathrm{M}$, Cerullo $\mathrm{V}$, Pesonen $\mathrm{S}$, et al. In vivo magnetic resonance imaging and spectroscopy identifies 
oncolytic adenovirus responders. International journal of cancer Journal international du cancer. 2013.

54. Parviainen S, Ahonen M, Diaconu I, Kipar A, Siurala M, Vaha-Koskela M, Kanerva A, Cerullo V, Hemminki A. GMCSF-armed vaccinia virus induces an antitumor immune response. International journal of cancer Journal international du cancer. 2014.

55. Cho SA, Park JH, Seok SH, Juhn JH, Kim SJ, Ji HJ, Choo YS. Effect of granulocyte macrophage-colony stimulating factor (GM-CSF) on 5-FU-induced ulcerative mucositis in hamster buccal pouches. Experimental and toxicologic pathology: official journal of the Gesellschaft fur Toxikologische Pathologie. 2006; 57:321-328.

56. Cohen AM, Hines DK, Korach ES, Ratzkin BJ. In vivo activation of neutrophil function in hamsters by recombinant human granulocyte colony-stimulating factor. Infection and immunity. 1988; 56:2861-2865.

57. Koski A, Kangasniemi L, Escutenaire S, Pesonen S, Cerullo V, Diaconu I, Nokisalmi P, Raki M, Rajecki M, Guse K, Ranki T, Oksanen M, Holm SL, Haavisto E, Karioja-Kallio A, Laasonen L, et al. Treatment of cancer patients with a serotype $5 / 3$ chimeric oncolytic adenovirus expressing GMCSF. Mol Ther. 18:1874-1884.

58. Cerullo V, Diaconu I, Kangasniemi L, Rajecki M, Escutenaire S, Koski A, Romano V, Rouvinen N, Tuuminen T, Laasonen L, Partanen K, Kauppinen S, Joensuu T, Oksanen M, Holm SL, Haavisto E, et al. Immunological effects of low-dose cyclophosphamide in cancer patients treated with oncolytic adenovirus. Mol Ther. 19:1737-1746.

59. Liikanen I AL, Kangasniemi L, Cerullo V, Nokisalmi P, Escutenaire S, Diaconu I, Pesonen S, Koski A, Haavisto E, Partanen K, Joensuu T, Kanerva A, Hemminki A. Treatment of Cancer with Oncolytic Adenovirus Combined with Temozolomide, an Autophagy Inducer. 2011; ASGCT: Mol Ther.

60. Cerullo V, Diaconu I, Kangasniemi L, Rajecki M, Escutenaire S, Koski A, Romano V, Rouvinen N, Tuuminen T, Laasonen L, Partanen K, Kauppinen S, Joensuu T, Oksanen M, Holm SL, Haavisto E, et al. Immunological effects of low-dose cyclophosphamide in cancer patients treated with oncolytic adenovirus. Molecular therapy: the journal of the American Society of Gene Therapy. 2011; 19:1737-1746.

61. Hemminki O, Diaconu I, Cerullo V, Pesonen SK, Kanerva A, Joensuu T, Kairemo K, Laasonen L, Partanen K, Kangasniemi L, Lieber A, Pesonen S, Hemminki A. Ad3hTERT-E1A, a Fully Serotype 3 Oncolytic Adenovirus, in Patients With Chemotherapy Refractory Cancer. Molecular therapy: the journal of the American Society of Gene Therapy. 2012.

62. Nettelbeck DM, Rivera AA, Balague C, Alemany R, Curiel DT. Novel oncolytic adenoviruses targeted to melanoma: specific viral replication and cytolysis by expression of E1A mutants from the tyrosinase enhancer/ promoter. Cancer Res. 2002; 62:4663-4670.

63. Ruifrok AC, Johnston DA. Quantification of histochemical staining by color deconvolution. Analytical and quantitative cytology and histology / the International Academy of Cytology American Society of Cytology [and] American Society of Cytology. 2001; 23:291-299.

64. Dunning MJ, Smith ML, Ritchie ME, Tavare S. beadarray: $\mathrm{R}$ classes and methods for Illumina bead-based data. Bioinformatics. 2007; 23:2183-2184.

65. Durinck S, Moreau Y, Kasprzyk A, Davis S, De Moor B, Brazma A, Huber W. BioMart and Bioconductor: a powerful link between biological databases and microarray data analysis. Bioinformatics. 2005; 21:3439-3440. 